\title{
Role of protozoans on the microbial ectoenzymatic activity during the degradation of macrophytes
}

\author{
M. Montserrat Sala ${ }^{1, *}$, Hans Güde ${ }^{2}$ \\ ${ }^{1}$ Institut de Ciències del Mar, Passeig Joan de Borbó s/n, 08039 Barcelona, Spain \\ ${ }^{2}$ Institut für Seenforschung, Untere Seestr. 81, 88085 Langenargen, Germany
}

\begin{abstract}
A succession of microbial populations and ectoenzymatic activities was observed during the decomposition of the dissolved organic matter (DOM) leached from the macrophyte Potamogeton pectinatus. In an initial phase, free bacterial populations dominated. These bacteria produced ectoenzymes to hydrolyze dissolved carbohydrates (maltose, cellobiose and starch). When bacterivorous Protozoa entered the sample, free bacteria almost disappeared and most of the bacteria were then found attached, colonizing the macrophyte particles. Protozoan populations also showed a succession where heterotrophic nanoflagellates (HNF) grew first and then larger Protozoa, ciliates and amoeba, developed. During this second phase, high activities of degradation of structural polysaccharides such as cellulose and hemicellulose were detected. HNF seemed to play an important role during the degradation of macrophytes because they grazed mainly on free bacteria and left the attached bacteria to grow. Thus, they promoted a shift from the hydrolysis of non-structural to structural polysaccharides.
\end{abstract}

KEY WORDS: Ectoenzyme $\cdot$ Macrophyte degradation $\cdot$ Temperature $\cdot$ Protozoan

\section{INTRODUCTION}

Macrophytes constitute an important component of the living biomass in the littoral zone of lakes (Wetzel et al. 1972), where they are practically the only source of dissolved organic matter (DOM) for many freshwater ecosystems (Wetzel 1990, Pieczynska 1993). However, it seems that the contribution of macrophytes to the secondary production in littoral waters occurs mainly through the degradation of detritus (Polunin 1982). The first step is called leaching, and is the direct loss of DOM from the macrophytes (Godshalk \& Wetzel 1978, Polunin 1982). Microorganisms are not involved in this step of the degradation of macrophytes, but they are able to utilize this DOM for their metabolism (Hansen et al. 1986). Consequently, a microbial colonization of the macrophytes follows (Fenchel 1970, Kaushik \&

\footnotetext{
•E-mail: msala@icm.csic.es
}

Hynes 1971, Mason 1976, Cole \& Likens 1979, Sridhar \& Bärlocher 1993). Most of this organic matter is present in the form of high molecular weight compounds (HMWC) that bacteria cannot directly utilize without hydrolyzing it enzymatically (Chróst 1990). This process is accomplished through the activity of microbial ectoenzymes.

Since ectoenzymes are usually specific, a determination of ectoenzymatic activities should be an indirect estimation of the molecules being utilized by the bacterial populations. Thus, the determination of the ectoenzymatic activities involved in the hydrolysis of carbohydrates should be a good indicator of the degradation of these molecules in the macrophyte leachate. Previous studies have already shown the importance of 2 ectoenzymes, cellulase and xylanase, in the degradation of reeds (Tanaka 1991, 1993), leaves (Sinsabaugh et al. 1981) and detritus (Sinsabaugh \& Linkins 1993, Sinsabaugh et al. 1994). These authors followed the activities of these en- 
zymes, weekly, for several months. In our study, we hypothesized that ectoenzymatic activities must play a basic role for the degradation of the DOM leached during the initial phase as well as the final phase of macrophyte decomposition. To resolve this, we increased the sampling frequency from monthly to daily. Then, we followed the development of microbial populations and activities of 6 ectoenzymes that hydrolyze carbohydrates in enriched laboratory cultures. Experiments on degradation were conducted at different temperatures and at different levels of protozoan grazing.

\section{MATERIAL AND METHODS}

Experimental design. Macrophytes were collected by divers from the littoral zone of Lake Constance during dulumn. The chosen species was Potamogeton pectinatus, one of the most abundant macrophytes in the littoral zone of Lake Constance (Geller \& Güde 1989). Plants were dried and reduced to a fine powder which was used as a substrate for the enrichments. This powder was first heated at $100^{\circ} \mathrm{C}$ for $30 \mathrm{~min}$ in order to destroy the possible ciliate cysts.

For Expt 1, $5 \mathrm{~g}$ of macrophyte powder was added to 5 I of unfiltered surface water of the littoral zone of Lake Constance. Containers $(50 \mathrm{~cm}$ height and $30 \mathrm{~cm}$ diameter) were made of glass and consisted of a pipe prolonged by a cone. The 4 containers, 2 treatments with 2 replicates each, were maintained under constant aeration by bubbling and in the dark at 2 different temperatures, 5 and $20^{\circ} \mathrm{C}$.

In Expt 2, some of the macrophyte powder (100 mg) was added to $200 \mathrm{ml}$ of sterile lake water, filtered through $0.2 \mu \mathrm{m}$ pore size filter (Nuclepore). The inoculate was $20 \mathrm{ml}$ of lake water filtered through a $3.0 \mu \mathrm{m}$ pore size filter in the samples, or through $1.0 \mu \mathrm{m}$ in the control, to avoid the presence of Protozod. The 4 containers were incubated at $20^{\circ} \mathrm{C}$ under constant aeration and dim light. We succeeded in keeping only 1 of the controls protozoan-free throughout the experiment, so we only show data for this control (a). As the abundance of heterotrophic nanoflagellates (HNF) was different in the 2 replicates, results are shown separately, where Treatment $c$ is the replicate with higher HNF abundance and Treatment $b$ the one with lower HNF abundance.

Methods. Bacterial and protozoan abundances were examined by direct counts under epifluorescence microscope after staining the sample with 4'-6diamidino-2-phenylindol dihydrochloride (DAPI) and filtering the sample through a black $0.2 \mu \mathrm{m}$ Nuclepore filter for bacteria, and a $0.8 \mu \mathrm{m}$ filter for protozoa, following Porter \& Feig (1980). Protozoa were differenti- ated among HNF, ciliates and amoeba. Protozoan biovolume was calculated by approximation to the nearest geometric shape from measurements of cell length and width of each different protozoan cell. We approximated the shape of ciliates and HNF to an ellipsoid. For amoeba, we considered the cell as an elliptical disc, with a height of $10 \%$ of the mean value of the diameters of the ellipse.

For the determination of ectoenzymatic activities, 2 different methods were followed. The remazol brilliant method was based on the hydrolysis of chromogenic substrates following the method from Wirth \& Wolf (1992) and modified by Sala \& Güde (1996). Subsamples $(0.4 \mathrm{ml})$ were incubated with $0.2 \mathrm{ml}$ of remazollinked substrate solution $0.4 \mathrm{mg} \mathrm{l}^{-1}$ (RBB-cellulose, RBB-starch and RBB-xylane) and $0.4 \mathrm{ml}$ of Tris-HCl buffer $\mathrm{pH} 8.3$, final concentration $0.01 \mathrm{M}$, in 2 replicates for $24 \mathrm{~h}$ at $36^{\circ} \mathrm{C}$. The reaction was stopped by adding, in an ice bath, $0.2 \mathrm{ml}$ of $2 \mathrm{~N} \mathrm{HCl}$. In consequence, the hydrolyzed polysaccharide remained in the solution while the non-hydrolyzed substrate precipitated. After centrifugation, the absorbance of the supernatant was read spectrophotometrically at $600 \mathrm{~nm}$. The activity units were calculated by subtracting the mean absorbance of 2 blanks, samples kept at $80^{\circ} \mathrm{C}$ during $30 \mathrm{~min}$ for enzyme inactivation and incubated and treated as the samples.

The activities of $\alpha$ - and $\beta$-glucosidase, and exocellulase were determined by a fluorimetric method (Hoppe 1983) modified from Schmitt-Biegel \& Obst (1989). The activity was measured by the cleavage of the non-fluorescent substrates linked to the 4 -methylumbelliferyl molecules that emit fluorescence once hydrolyzed (see Hoppe 1993). The substrates we used were: 4-MUF$\alpha$-D-glucoside, 4-MUF- $\beta$-D-glucoside, 4-MUF- $\beta$-D-cellobiopyranoside. The assay was carried out in a microtiter well-plate in 2 replicates consisting of a $200 \mu \mathrm{l}$ subsample, a $20 \mu \mathrm{l}$ substrate $(200 \mu \mathrm{M}$ final concentration) and $20 \mu$ of Tris-HCl buffer $\mathrm{pH}$ 8.3. After incubation at room temperature for $1 \mathrm{~h}$, the fluorescence was measured at $365 \mathrm{~nm}$ excitation and $460 \mathrm{~nm}$ emission wavelengths. The increase of fluorescence was converted to enzymatic activity with a standard curve of 4 -methylumbelliferone, the final product of the reaction. Several substrate concentrations $(20,50,100,200$ and $500 \mu \mathrm{M}$ ) were investigated every time and $200 \mu \mathrm{M}$ was always saturating.

The studied activities were mostly involved in the hydrolysis of polysaccharides. Endoamylase and $\alpha$ glucosidase hydrolyze polymers and dimers of starch, respectively. Endocellulase, exocellulase and $\beta$-glucosidase hydrolyze the polysaccharide, oligosaccharide and disaccharide, respectively, of cellulose. Endoxylanase hydrolyzes xylane, a polymer of xylose which forms hemicellulose. 


\section{RESULTS}

\section{Expt 1}

The growth of bacterial and protozoan populations was followed during the first $28 \mathrm{~d}$ of the experiment. The first microorganisms growing at $20^{\circ} \mathrm{C}$ were bacteria, achieving concentrations higher than $1 \times 10^{8}$ cell $\mathrm{ml}^{-1}$ on the second day of incubation (Fig. 1a). This initial maximum decreased quickly and remained low during the next $5 \mathrm{~d}$. This period of low bacterial concentration coincided with the appearance of HNF.
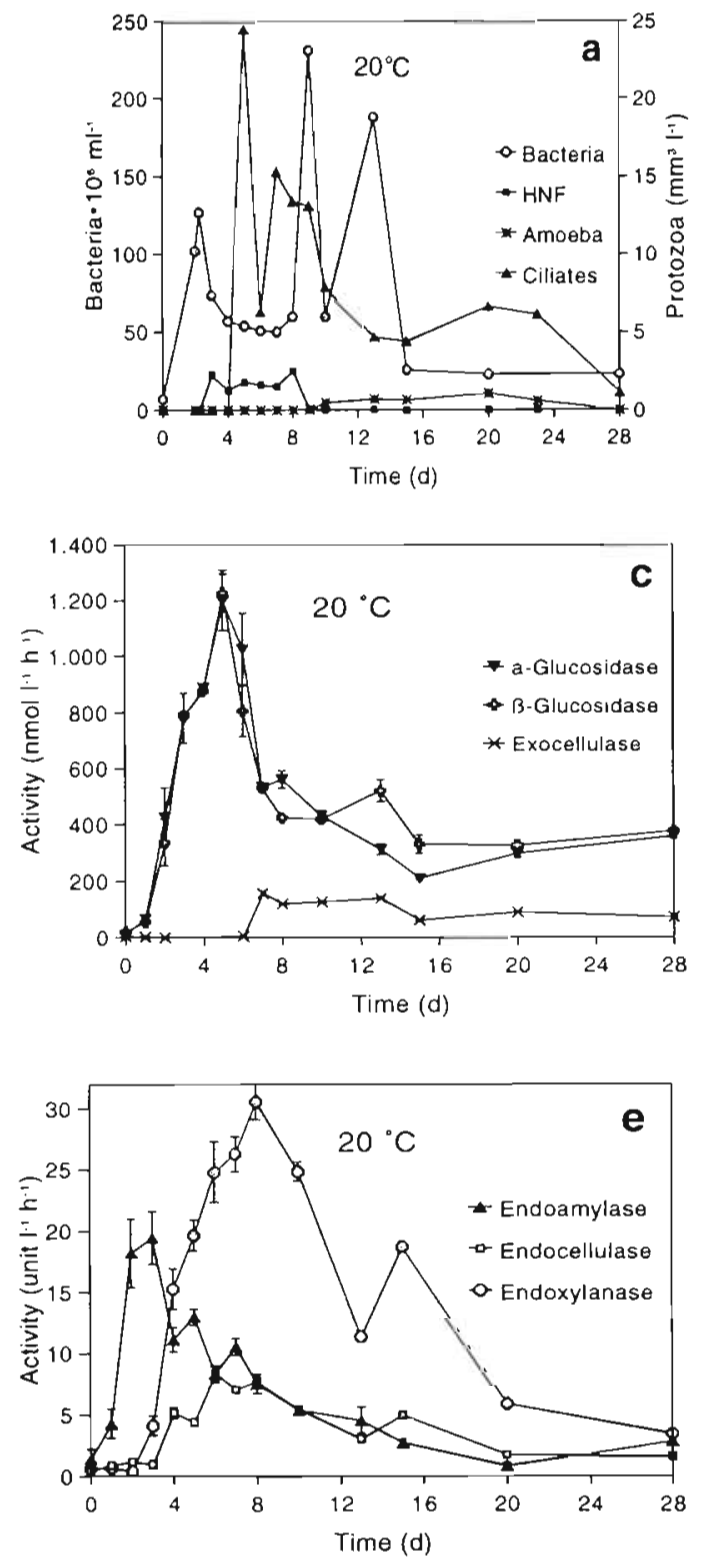

After some days, a population of ciliates developed. These ciliates probably fed on HNF and caused the disappearance of these populations. When HNF disappeared, bacterial populations exhibited a maximum which later fluctuated due to the different interactions between predators and possible prey. Another larger protozoan was also seen during the last days of incubation: a population of amoeba that co-occurred with the always abundant ciliates

The enrichments at $5^{\circ} \mathrm{C}$ showed a lower variety in the composition of microorganisms because the succession was slower. From Day 28 onwards, ciliates
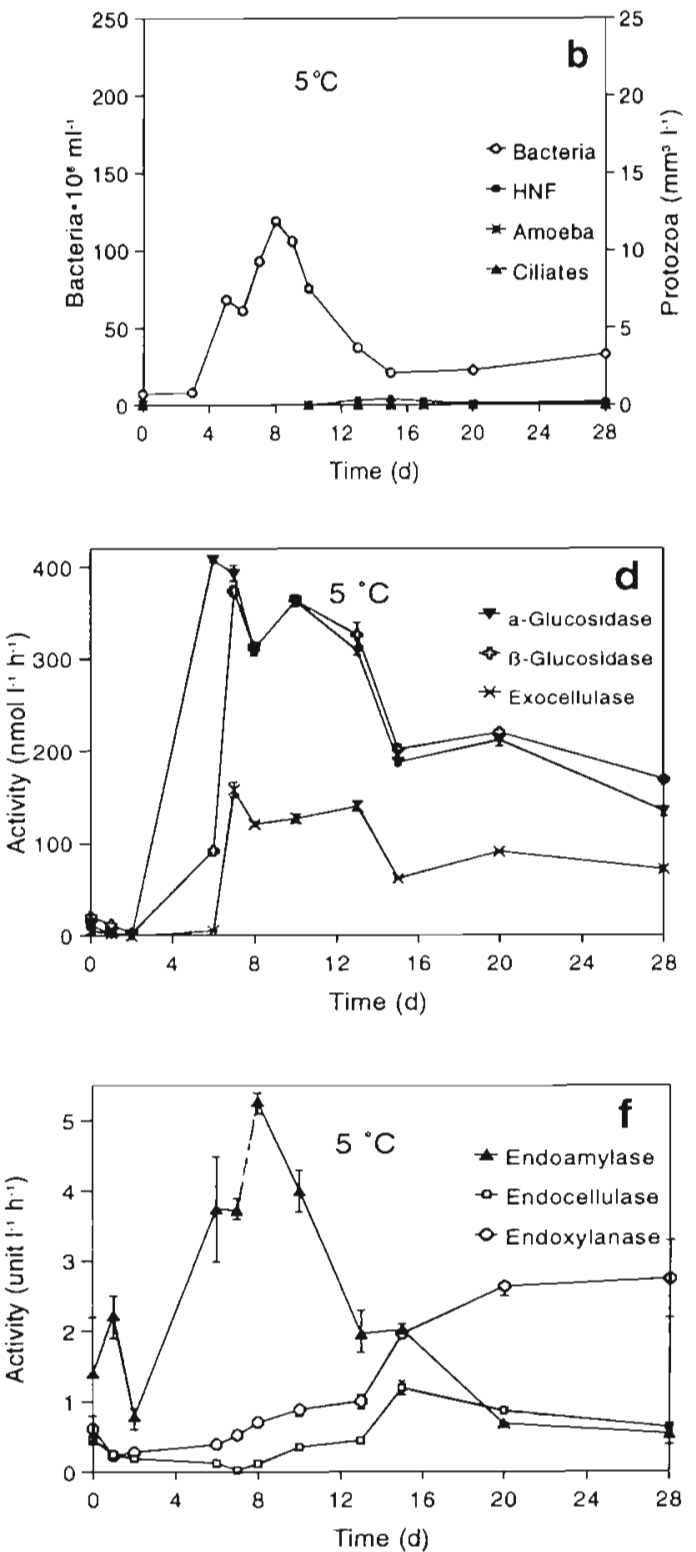

Fig. 1. Succession of bacterial and protozoan populations in the enrichments at (a) $20^{\circ} \mathrm{C}$ and (b) $5^{\circ} \mathrm{C}$ of Expt 1 and of enzyme activities: (c, d) $\alpha$ - and $\beta$-glucosidase and exocellulase and $(e, f)$ endoenzymes in the cultures at 20 and $5^{\circ} \mathrm{C}$ of Expt 1 . Bars indicate 
were also observed. The bacterial maximum was detected at Day 8 (Fig, 1b) and was also later followed by a small peak of $\mathrm{HNF}$.

At $20^{\circ} \mathrm{C}$ a succession of activities of degradation of carbohydrates could be observed. During the first $5 \mathrm{~d}$ initial maxima of amylolytic activity and glucosidases $(\alpha$ and $\beta$ ) appeared (Fig. 1c,e). When these activities decreased, the activities of endocellulase and exocellulase started increasing to 10 units $\mathrm{l}^{-1} \mathrm{~h}^{-1}$ and almost $200 \mathrm{nmol} \mathrm{l}^{-1} \mathrm{~h}^{-1}$, and especially for endoxylanase, which after the maximum at Day 8 (of about 10 units $\mathrm{l}^{-1} \mathrm{~h}^{-1}$ ) started decreasing.

At $5^{\circ} \mathrm{C}$ a similar succession of ectoenzymatic activities could be observed which were slower and less intense (Fig. 1d,f). The lower speed of the succession allowed a better appreciation of the order of appearance of the ectoenzymatic activities: before Day $6, \alpha$-glucosidase activity increased, and at Day $7 \beta$-glucosidase and exocellüase increased. Among endoenzymes, endoamylolytic activity appeared first, forming a peak at the same time as glucosidases. When this activity started decreasing, endocellulase and endoxylanase activities increased and remained high during the rest of the experiment.

\section{Expt 2}

The microbial populations that developed in the treatments were only bacteria and HNF because larger Protozoa had been eliminated by filtration through $3 \mu \mathrm{m}$. Without HNF, bacteria reached higher densities (Fig. 2a). From Day 4 onwards, bacterial concentration in the controls was higher than $1 \times 10^{8}$ cells $\mathrm{ml}^{-1}$, while in the samples with Protozoa maximal abundances were 7 and $5 \times 10^{7} \mathrm{ml}^{-1}$ (Fig. $2 \mathrm{~b}, \mathrm{c}$ ), respectively. One day after this initial maximum of bacterial concentration, a peak of HNF was detected. This peak was higher in Treatment $\mathrm{c}$ and high concentrations of HNF were detected until Day 14. In treatment $b$, the peak of HNF was also at Day 4 and the next day the concentration decreased to values below 20000 cells $\mathrm{ml}^{-1}$.

From the moment when the HNF concentration increased, the percentage of bacteria attached to particles also increased. The percentage of attached bacteria ranged between 0 and $10 \%$ before Protozoa increased, and oscillated around $20 \%$ with maximum values of $38 \%$ thereafter. In the control, however, the number of attached bacteria was always between 0 and $5 \%$.

Microscopical observations showed a dominance of free bacteria in the treatment without Protozoa (Fig. 2a). In the treatments with Protozoa (Fig. 2b,c), free bacteria were also found at the beginning but when HNF developed in the sample, the number of attached bacteria increased. After the grazing pressure diminished, free cells appeared again.
The ectoenzymatic activities investigated showed a succession similar to that described above for Expt 1, with a first peak of amylolytic activity, followed by the appearance of activities involved in the hydrolysis of smaller carbohydrates $(\alpha$-glucosidase, $\beta$-glucosidase and exocellulase) (Fig. 3). Later, high values of endocellulase and endoxylanase were obtained. Ectoenzymatic activities were lower in the presence of Protozoa (Fig. $3 \mathrm{~b}, \mathrm{c}$ ). The only exception was $\beta$-glucosidase, which achieved $8000 \mathrm{nmol}^{-1} \mathrm{~h}^{-1}$ after $5 \mathrm{~d}$ of incubation.
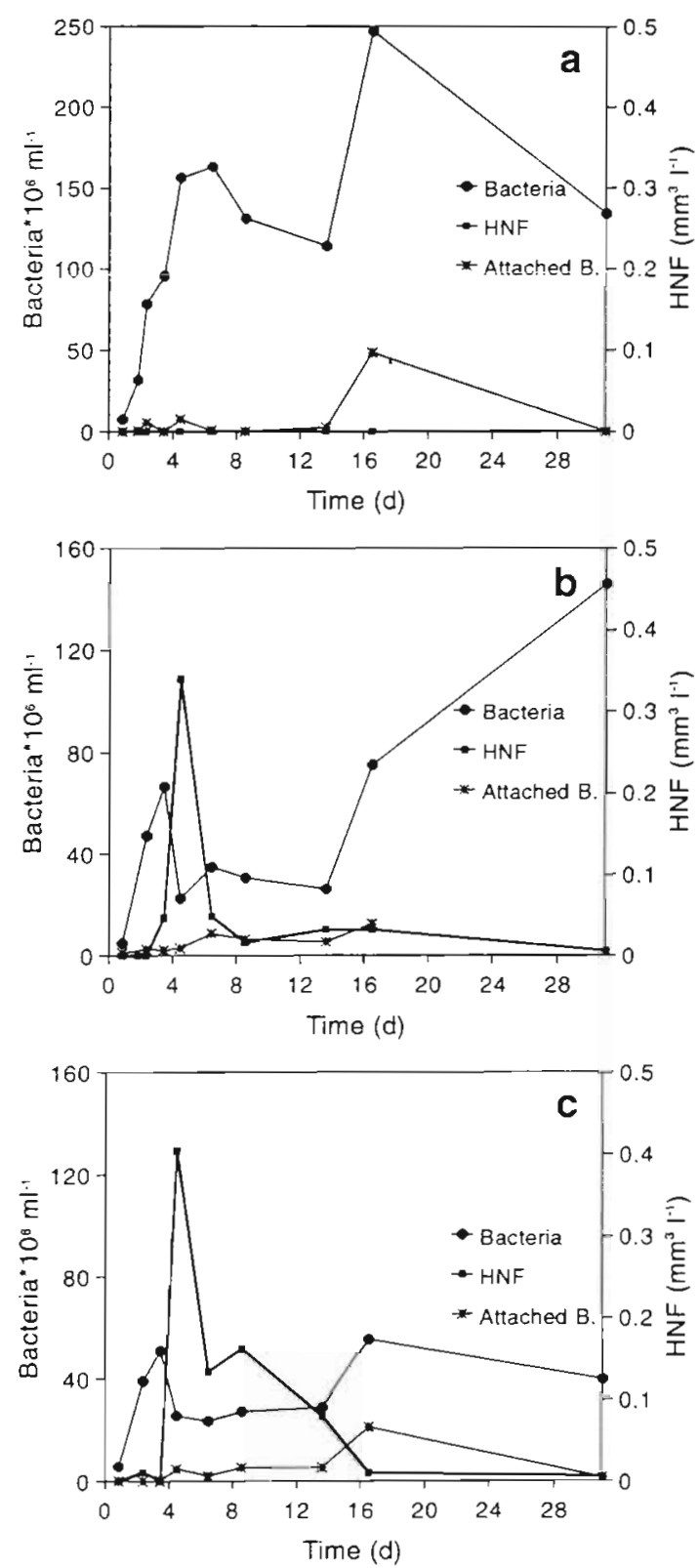

Fig. 2. Total bacterial concentration, attached bacteria an heterotrophic nanoflagellates (HNF) in (a) the control without Protozoa, and in $(b, c)$ Treatments b and $c$, replicates with Protozoa, in Expt 2 

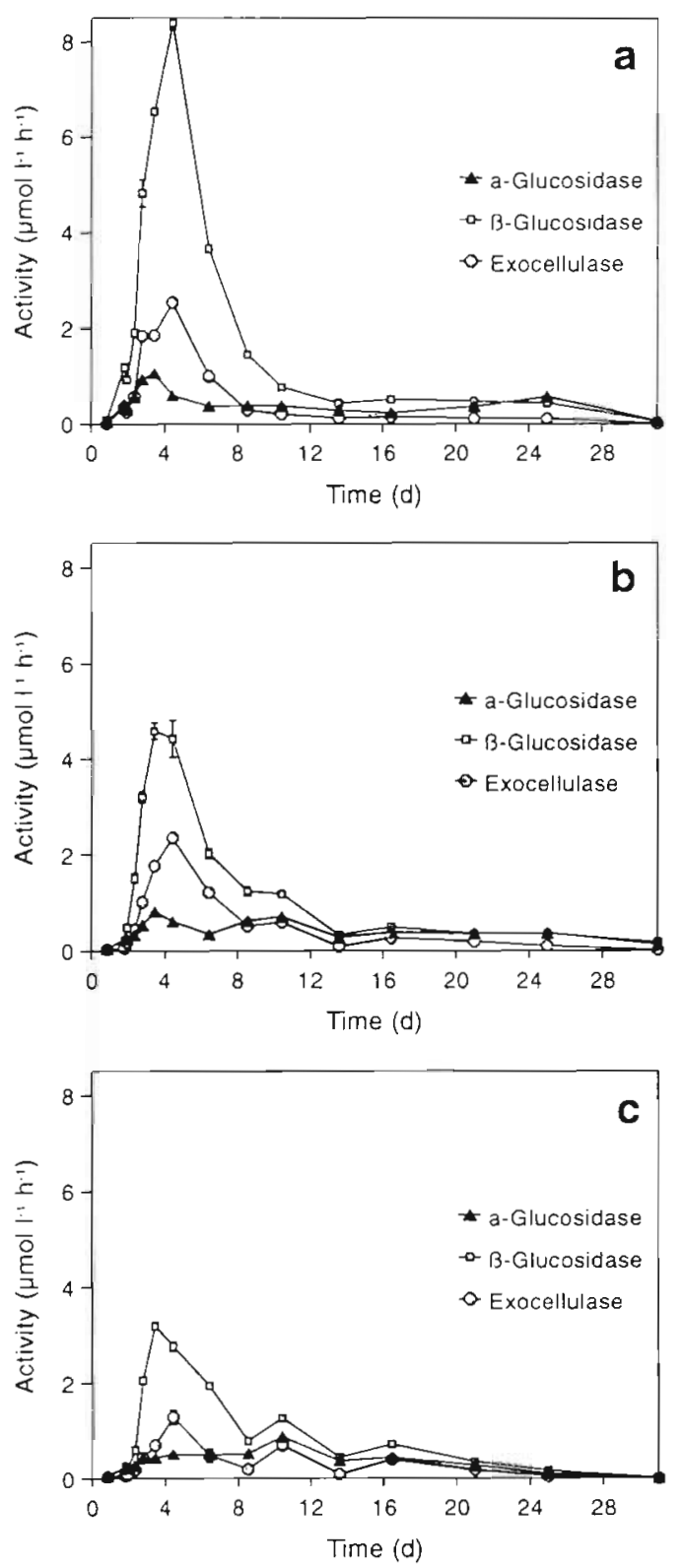

Fig. 3. Succession of $\alpha$-and $\beta$-glucosidase and exocellulase in the treatments $b$ and $c$, replicates with protozoa, and in the control (a) without Protozoa in Expt 2. Bars indicate standard errors of the mean of 2 measurements

The activities of $\alpha$-glucosidase and exocellulase were of comparable intensity in the control and in the samples, so the specific activity is higher in presence of HNF.

The activities involved in the degradation of polysaccharides were generally higher with Protozoa (Fig. 4b,c). Without Protozoa (Fig. 4a), endoamylolytic activity showed a maximum of lower intensity and the appearance of endoxylanolytic and endocellulolytic activities was at a later stage compared to the treatment containing $\mathrm{HNF}$.
The differences observed in ectoenzymatic activities seemed to follow the changes in bacterial and protozoan numbers. Some differences were seen in both samples with different concentration of HNF. With lower concentration of HNF during a shorter period of time (Fig. 2b), enzyme activity patterns were more similar to those obtained in the control (Fig. 2a) than the ones obtained for the treatment with a higher grazing pressure (Fig. 2c).
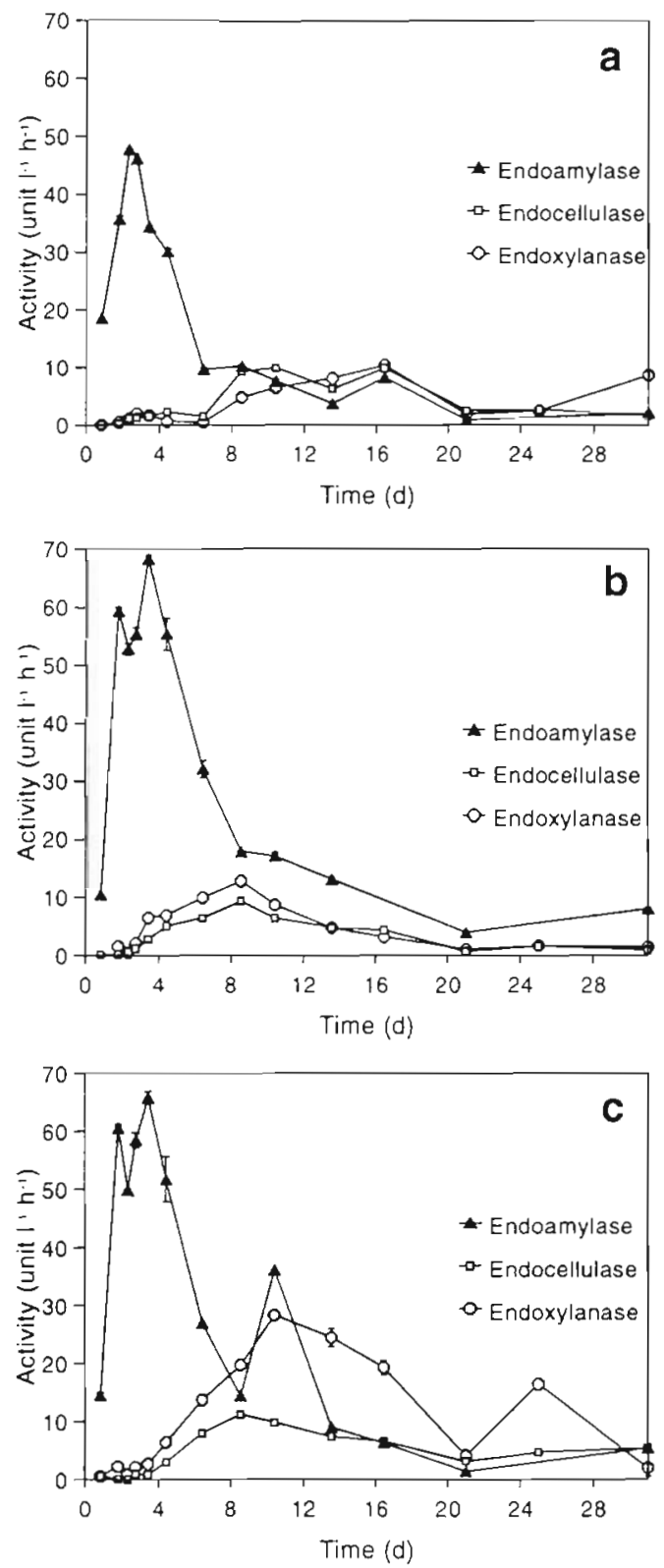

Fig. 4. Succession of endoenzymatic activities in the treatments b and $c$, replicates with protozoa, and in the control (a) without Protozoa in Expt 2. Bars indicate standard errors of the mean of 2 measurements 


\section{DISCUSSION}

In both experiments, in the initial phase of the degradation, a high growth of free bacteria was observed, probably due to the utilization of dissolved organic substances (Oláh 1972), which they seem to prefer over particulate organic carbon (Newell et al. 1981).

This first phase of the degradation was characterized by a high activity of endoamylase and $\alpha$-glucosidase, i.e. hydrolysis of starch and derivatives. Several authors (Fukami et al. 1981, Gunatilaka et al. 1990, Belova 1993) also suggested that during the first steps of decomposition the labile carbohydrates stimulated bacterial growth. These results agree with the observations of Godshalk \& Wetzel (1978), who suggested that the hydrolysis of non-structural carbohydrates (free sugars and starch) occurred before the degradation of the structural components. During this first phase, however, high activilies of $\beta$-giucosidase were detected. One of the possible explanations is that molecules of cellobiose, disaccharide of glucose and substrate for $\beta$-glucosidase could have been released by leaching. Bacteria would probably have preferred to use this disaccharide, instead of hydrolyzing cellulose, for what they need to produce 3 different enzymes: endocellulose, exocellulose and $\beta$-glucosidase.

After this first phase the proportion of free bacteria decreased, increasing that of attached bacteria. This coincided with the period of higher grazing pressure by HNF, and bacterial concentration was maintained at low levels. The high number of attached bacteria found by Oláh (1972) and Fukami et al. (1981) in their experiments of decomposition of phragmites and phytoplankton could have also been related to the grazing pressure by HNF.

In later stages of the succession, when amoeba and ciliates were the dominant Protozoa, bacterial abundance showed a higher dynamic, probably due to the grazing pressure of larger Protozoa on the main bacterial consumers, the HNF. During this third phase of the process of decomposition, high activities of degradation of cellulose (endocellulase) and xylane (endoxylanase) were observed. These activities were very probably repressed during the initial phases of degradation due to the availability of labile carbohydrates. The combination of activities of endocellulase and endoxylanase could be seen as an indication of the hydrolysis of structural polysaccharides. This phase coincided, moreover, with the phase of higher loss of weight (data not shown here) of the particulate carbon, as was also observed by Belova (1993) and Tanaka (1991). These enzymes are the agents that directly mediate the rate limiting steps in litter degradation (Sinsabaugh \& Linkins 1993). This order of degrada- tion reflects the different stability of the carbohydrates present in plant cells (Opsahl \& Benner 1993).

The temporal succession of the microbial populations and ectoenzymatic activities showed a very similar pattern at both temperatures. However, it was much slower and of a lower intensity at $5^{\circ} \mathrm{C}$ than at $20^{\circ} \mathrm{C}$. Güde (1978) also observed the appearance of amylolytic, cellulolytic and xylanolytic bacteria during the degradation of Scenedesmus sp., also exhibiting a delay of 10 days between the peak activities achieved at 20 and $5^{\circ} \mathrm{C}$. Structural carbohydrates are hydrolyzed faster at $25^{\circ} \mathrm{C}$ than at $10^{\circ} \mathrm{C}$ (Godshalk \& Wetzel 1978), as can be seen indirectly by the development of the activities of ectoenzymes responsible for their cleavage (endocellulase and endoxylanase) at both temperatures.

The shift from a mainly free-living bacterial community that hydrolyzes small or non-structural carbohydrates to mainly attached populations that hydrolyze structural carbohydrates could have 2 possible explanations: non-structural carbohydrates had already been consumed and/or free bacteria were predated selectively by Protozoa, thus favoring the attached bacterial populations. Expt 2 was designed to test these 2 hypotheses.

The protozoan populations that developed in the containers in Expt 2 controlled the bacterial concentration as was also observed by Harrison \& Mann (1975). Grazing was probably centered on free-living bacteria, since the presence of attached bacteria increased with the appearance of a high concentration of HNF that caused a decrease in the bacterial concentration (Newell et al. 1981, Robertson et al. 1982, Gunatilaka et al. 1990). HNF could maintain a more active population because specific activities of bacteria growing in the presence of HNF were higher. The succession of events in the samples with Protozoa started with a high proliferation of free bacteria, and the community was composed of few morphological types. During this time bacteria utilized easily available dissolved substrates. With the appearance of HNF in the sample, the percentage of attached bacteria increased (Jürgens \& Güde 1994). At the same time, the activities of hydrolysis of non-structural carbohydrates declined, while the hydrolysis of structural polysaccharides increased.

This succession of ectoenzymatic activities could also be seen in the absence of Protozoa, although it was slower because the hydrolysis of structural carbohydrates started later. The proportion of attached bacteria was almost always lower, except for Day 16. The percentage of attached bacteria on this day was about $25 \%$. This could be due to the fact that the high concentration of bacteria may have caused an aggregation of the cells and was not related to grazing. The 
general trend observed, that the proportion of bacteria attached is lower in Treatment $a$, indicates that Protozoa are very probably responsible for the shift from a basically free-living community with small bacteria, to one of a more morphologically diverse community with a higher proportion of attached bacteria that is based on the hydrolysis of particles. The higher speed and intensity of the succession when Protozoa were present could be due to the fact that Protozoa favored a shift in the bacterial community by grazing (Šimek et al. 1997). The possibility that part of the ectoenzymes were produced by HNF, as has been recently observed by Karner et al. (1994), could not be tested in our experiment

In summary, this paper has described a succession of ectoenzymatic activities involved in the hydrolysis of carbohydrates during the microbial degradation of macrophytes. This succession started with the hydrolysis of small and non-structural carbohydrates and was followed by the hydrolysis of larger structural polysaccharides as cellulose and hemicellulose (Fig. 5a). This succession occurred more slowly at $5^{\circ} \mathrm{C}$ than at $20^{\circ} \mathrm{C}$. The microbial community that appeared in the enrichments with macrophytes also showed a shift in composition. After an initial peak of bacteria, HNF appeared and through grazing controlled bacterial numbers.
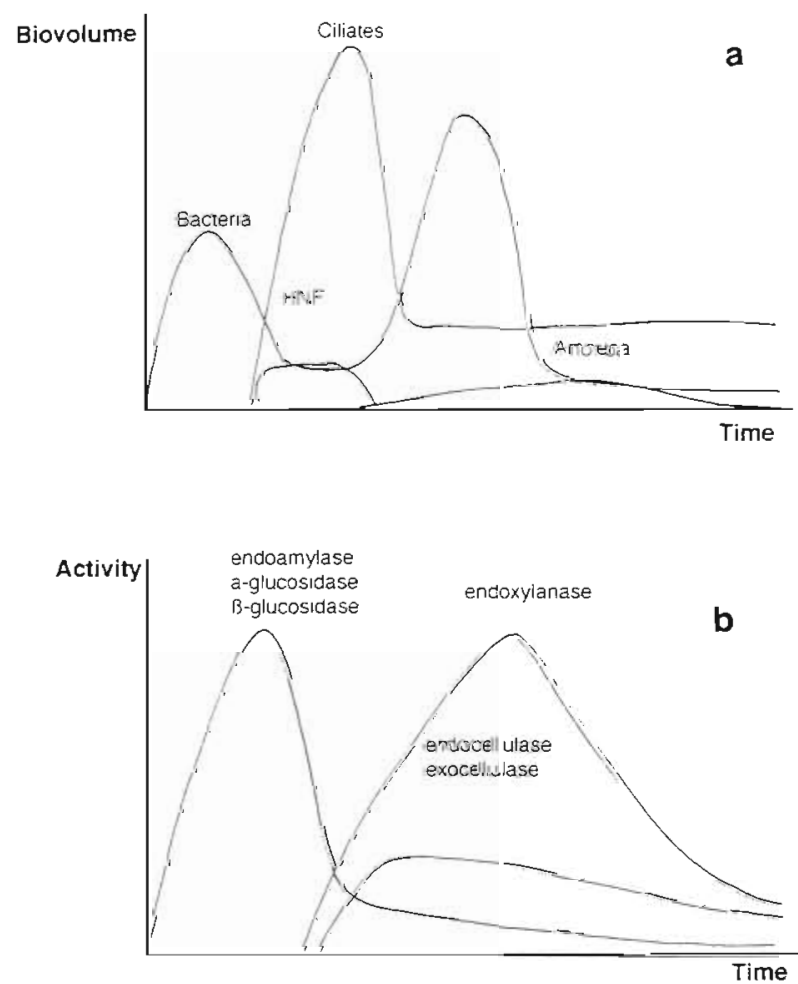

Fig. 5. Scheme of the succession of microbial populations (a) of ectoenzymatic activities (b) involved in the degradation of polysaccharides during the degradation of macrophyte powder
Afterwards, larger Protozoa such as ciliates and amoeba appeared in the treatments, HNF concentration decreased and bacterial concentration showed some oscillations (Fig. 5b). Our results indicate that Protozoa speed up the succession of ectoenzymatic activities observed (Fig 5a) by causing a shift in the bacterial community from a free-living population that mainly hydrolyzes non-structural substrates to an attached population which hydrolyzes structural polysaccharides.

Further research is needed in this field to test, for example, if the succession of ectoenzymatic activities described here can be also found during the degradation of other sources of detritus, and also to evaluate the influence of other planktonic organisms on the development of this succession.

Acknowledgements. We want to thank R. Walser for collecting the macrophytes and J. M. Gasol for kindly revising the manuscript. This study was supported by the joint research project 'Cycling of organic matter in Lake Constance' and M.M.S obtained a grant from the Spanish Ministry of Education and Sciences.

\section{LITERATURE CITED}

Belova M (1993) Microbial decomposition of freshwater macrophytes in the littoral zone of lakes. Hydrobiologia $251: 59-64$

Chróst RJ (1990) Microbial ectoenzymes in aquatic environments. In: Overbeck J, Chróst RJ (eds) Aquatic microbial ecology: biochemical and molecular approaches. Springer Verlag; New York, p 47-78

Cole JJ, Likens GE (1979) Measurements of mineralization of phytoplankton detritus in an oligotrophic lake. Limnol Oceanogr 24:541-547

Fenchel T (1970) Studies on the decomposition of organic detritus derived from the turtle grass Thalassia tes tudinum. Limnol Oceanogr 15:14-40

Fukami K, Simidu U, Taga N (1981) Fluctuation of the communities of heterotrophic bacteria during the decomposition process of phytoplankton. J Exp Mar Biol Ecol 55: $171-184$

Geller U, Güde H (1989) Lake Constance. The larger German lake. In: Lampert W, Rothhaupt $\mathrm{KO}$ (eds) Limnology in the Federal Republic of Germany. International Association for Theoretical and Applied Limnology, Plön, p 9-17

Godshalk GL, Wetzel RG (1978) Decomposition of aquatic angiosperms. II. Particulate components. Aquat Bot 5 : $301-327$

Güde H (1978) Polysaccharide degradation by aquatic Cytophaga populations in an eutrophic lake and in microbial mixed cultures. Verh Int Verein Limnol 20:2233-2237

Gunatilaka A, Mendez MC, Herndl G (1990) Microbial interactions during decomposition of phragmites litter. Arch Hydrobiol. Beih Ergebn Limnol 34:127-127

Hansen L, Krog GF, Sondergaard M (1986) Decomposition of lake phytoplankton. 1. Dynamics of short-term decomposition. Oikos $46: 37-44$

Harrison PG, Mann KH (1975) Detritus formation from eelgrass (Zostera marina L.): the relative effects of fragmentation, leaching and decay. Limnol Oceanogr 20:924-934 
Hoppe HG (1983) Significance of exoenzymatic activities in the ecology of brackish water: measurements by means of methylumbelliferyl substrates. Mar Ecol Prog Ser 11: $299-308$

Hoppe HG (1993) Use of fluorogenic model substrates for extracellular enzyme activity (EEA) measurement of bacteria. In: Kemp PF, Sherr BF, Sherr EB, Cole JJ (eds) Handbook of methods in aquatic microbial ecology. Lewis Publishers, Boca Raton, p 423-431

Jürgens K, Güde $H$ (1994) The potential importance of grazing-resistant bacteria in planktonic bacteria. Mar Ecol Prog Ser 112:169-188

Karner M, Ferrier-Pagès C, Rassoulzadegan F (1994) Phagotrophic nanoflagellates contribute to ocurrence of $\alpha$-glucosidase and aminopeptidase in marine environments. Mar Ecol Prog Ser 114:237-244

Kaushik NK, Hynes HBN (1971) The fate of dead leaves that fall into streams. Arch Hydrobiol 68:465-515

Mason CF (1976) Relative importance of fungi and bacteria in the decomposition of Phragmites leaves. Hydrobiologia $51: 65-69$

Newell RC, Lucas MI, Linley EAS (1981) Rate of degradation and efficiency of conversion of phytoplankton debris by marine microorganisms. Mar Ecol Prog Ser 6:123-136

Oláh J (1972) Leaching, colonization and stabilization during detritus formation. Mem Ist Ital Idrobiol 29(Suppl):105-127

Opsahl S, Benner R (1993) Decomposition of senescent blades of the seagrass Halodule wrightii in a subtropical lagoon. Mar Ecol Prog Ser 94:191-205

Pieczynska E (1993) Detritus and nutrient dynamics in the shore zone of lakes: a review. Hydrobiologia 251:49-58

Polunin NVC (1982) Processes contributing to the decay of reed (Phragmites australis) litter in fresh water. Arch Hydrobiol 94:182-209

Porter KG, Feig YS (1980) The use of DAPI for identifying and counting aquatic microflora. Limnol Oceanogr 25:943-948

Robertson ML, Mills AL, Zieman JC (1982) Microbial synthesis of detritus-like particulates from dissolved organic carbon released by tropical seagrasses. Mar Ecol Prog Ser 7 : $279-285$

Editorial responsibility: Karel Simek,

Ceské Budějovice, Czech Republic
Sala MM, Güde H (1996) Influence of algae and crustacean zooplankton on patterns of microbial hydrolytic enzyme activities - an experimental approach. Arch Hydrobiol Spec Iss Adv Limnol 48:143-154

Schmitt-Biegel B, Obst U (1989) Rationelle fluorimetrische Bestimmung von Enzymaktivitäten in vivo und der Biomasse (DNA) auf Mikrotiterplatten. Z Wasser-/Abwasser/ Forsch 22:165-167

Sunek K, Vrba K, Pernthaler J, Posch T, Hartman P, Nedoma J, Psenner R (1997) Morphological and compositional shifts in an experimental bacterial community influenced by protists with contrasting feeding modes. Appl Environ Microbiol 63(2):587-595

Sinsabaugh RL, Linkins AE (1993) Statistical modeling of litter decomposition from integrated cellulase activity. Ecology $74(5) ; 1594-1597$

Sinsabaugh RL, Benfield EF, Linkins AE (1981) Cellulase activity associated with the decomposition of leaf litter in a woodland stream. Oikos 36:184-190

Sinsabaugh RL, Osgood MP, Findlay S (1994) Enzymatic models for estimating decomposition rates of particulate detritus. J North Am Benthol Soc 13(2):160-169

Sridhar KR, Bärlocher F (1993) Seasonal changes in microbial colonization of fresh and dried leaves. Arch Hydrobiol 128: $1-12$

Tanaka Y (1991) Microbial decomposition of reed (Phragmites communis) leaves in a saline lake. Hydrobiologia 220 $119-129$

Tanaka Y (1993) Aerobic cellulolytic flora associated with decomposing Phragmites leaf litter in a seawater lake. Hydrobiologia 263:145-154

Wetzel RG (1990) Land-water interfaces: metabolic and limnological regulators. Verh Int Verein Limnol 24:6-24

Wetzel RG, Rich PH, Miller MC, Allen HL (1972) Metabolism of detrital carbon in a temperate hard-water lake. Mem Ist Ital Idrobiol 29(Suppl):185-243

Wirth SJ, Wolf GA (1992) Microplate colourimetric assay for endo-acting cellulase, xylanase, chitinase, 1,3-glucanase and amylase extracted from forest soil horizons. Soil Biol Biochem 24:511

Submitted: January 9, 1998; Accepted: May 5, 1999 Proofs received from author(s): November 10, 1999 